\title{
Hormone-sensitive lipase protein expression and extent of phosphorylation in subcutaneous and retroperitoneal adipose tissues in the periparturient dairy cow
}

\author{
L. F. Locher, ${ }^{\star}$ N. Meyer,† E.-M. Weber, ${ }^{\star}$ J. Rehage, ${ }^{*}$ U. Meyer,‡ S. Dänicke,‡ and K. Huber ${ }^{1}$ \\ ${ }^{*}$ Clinic for Cattle, and \\ †Department of Physiology, University of Veterinary Medicine Hannover, Foundation, 30171 Hannover, Germany \\ fInstitute of Animal Nutrition, Friedrich-Loeffler-Institute (FLI), Federal Research Institute for Animal Health, 38116 Braunschweig, Germany
}

\begin{abstract}
Lipomobilization is essential for dairy cows to balance the energy requirement for milk production in early lactation. This study aimed to determine the role of hormone-sensitive lipase (HSL) and its activation by phosphorylation at Ser 660 (HSLp660) and 563 (HSLp563) in different adipose tissue depots as influenced by time and postpartum diet in dairy cows. Biopsy samples were obtained from s.c. (SCAT) and retroperitoneal (RPAT) adipose tissues of 20 Holstein cows $21 \mathrm{~d}$ prepartum, and 1 and $21 \mathrm{~d}$ postpartum. After d 1 postpartum, cows were randomly assigned to 2 groups $(\mathrm{n}=10)$. Groups received diets with either a concentrate-to-roughage ratio on a dry matter basis of 30:70\% (low-concentrate, LC, group) or 60:40\% (highconcentrate group), fed until the third biopsy sampling $21 \mathrm{~d}$ postpartum. Dry matter intake, milk yield, and milk composition were recorded. Blood samples were taken weekly, starting $21 \mathrm{~d}$ prepartum and analyzed for nonesterified fatty acids, $\beta$-hydroxybutyrate (BHBA), glucose, and insulin. Protein expression of HSL and its extent of phosphorylation in adipose tissue were measured by semiquantitative Western blotting. Total HSL expression was lower in both adipose tissues $1 \mathrm{~d}$ after calving compared with prepartum sampling (SCAT: $4.10 \pm 0.5$ vs. $2.4 \pm 0.3$; RPAT: $11.1 \pm 1.3$ vs. $6.6 \pm 1.1$ ). Phosphorylation at Ser 660 was higher $21 \mathrm{~d}$ postpartum compared with $21 \mathrm{~d}$ prepartum in RPAT ( $2.9 \pm 0.3$ vs. $4.6 \pm 0.6)$. Phosphorylation at Ser 563 was higher $21 \mathrm{~d}$ postpartum than $21 \mathrm{~d}$ prepartum in SCAT $(0.6 \pm 0.1$ vs. $3.9 \pm 1.1$ ), and in RPAT a difference was observed between $21 \mathrm{~d}$ prepartum and $1 \mathrm{~d}$ postpartum $(1.0 \pm$ 0.1 vs. 3.3. \pm 0.6 ). On d 21 postpartum, the LC group showed a lower extent of Ser 563 phosphorylation in RPAT $(3.9 \pm 0.8$ vs. $10.0 \pm 1.9)$ and a higher concentration of serum BHBA $(0.77 \pm 0.05$ vs. $0.47 \pm 0.11)$ than
\end{abstract}

Received January 3, 2011.

Accepted May 16, 2011.

${ }^{1}$ Corresponding author: korinna.huber@tiho-hannover.de did the high-concentrate group. An inhibitory influence of higher BHBA concentrations on HSL phosphorylation in the LC group could be a possible explanation. On comparing RPAT to SCAT, HSL expression and the extent of Ser 660 and 563 phosphorylation was higher in RPAT at $21 \mathrm{~d}$ prepartum (HSL: $4.1 \pm 0.5$ vs. 11.1 \pm 1.2 ; HSLp660 $1.3 \pm 0.2$ vs. $2.9 \pm 0.3$; HSLp563: 0.6 \pm 0.1 vs. $1.0 \pm 0.1$ ). In conclusion, the postpartum feeding regimen influenced the phosphorylation pattern, especially in RPAT, implying a regulatory role for different phosphorylation sites in adaptive lipolysis of dairy cows. It is suggested that RPAT is more sensitive to periparturient challenges than is SCAT.

Key words: lipolysis, hormone-sensitive lipase, subcutaneous and retroperitoneal adipose tissue, cattle

\section{INTRODUCTION}

Lipolysis is the key metabolic pathway to provide endogenous energy in times of high energy demand. Dairy cows around parturition and early lactation depend on endogenous energy because of a marked decrease in dietary energy intake. Dietary energy intake is largely influenced by actual DMI, as well as energy density of the diet. To provide sufficient energy for milk production, large amounts of NEFA are mobilized from adipose tissues. Disturbance of lipolysis disposes dairy cows to a higher risk of developing hepatic lipidosis and ketosis with a subsequently decreased milk and reproduction performance (Drackley, 1999). Therefore, deregulation of lipolysis is seen as one of the major risk factors of dairy cows in the periparturient period. Lipolysis in the periparturient period among others is triggered by high energy requirements for lactation, decreased DMI (Ingvartsen and Andersen, 2000), and decreased insulin sensitivity of peripheral tissues (Hayirli, 2006). The initial step of lipolysis is the hydrolysis of triacylglycerols (Montague and O'Rahilly, 2000). In adipose tissue of cows, it is suggested that hydrolysis of triacylglycerols is mediated by hormone-sensitive lipase (HSL) under stimulation of catecholamines (Nilsson 
et al., 1989; Sumner and McNamara, 2007; Elkins and Spurlock, 2009). Yet, the exact physiological role of HSL in maintenance of energy homeostasis in dairy cows is not fully understood. The HSL is activated via phosphorylation by protein kinase A (PKA). This PKA is activated by elevated intracellular cyclic AMP (cAMP) concentrations resulting from $\mathrm{G}$ protein-coupled $\beta$-adrenergic receptor stimulation. This signaling pathway is probably existent in cows. It was shown by Jaster and Wegner (1981) that with the onset of lactation, the number of $\beta$-adrenoceptors in s.c. adipose tissue increased. Also, messenger RNA of all $\beta$-adrenergic receptors in bovine s.c. adipose tissue was more highly expressed during lactation than at d 30 before calving (Sumner and McNamara, 2007). Therefore, enhanced $\beta$-adrenergic signaling can be assumed in the periparturient and early lactation period. Activated PKA is able to phosphorylate HSL at 3 phosporylation sites (Ser 563, Ser 660, and Ser 659), thereby modulating its catalytic activity (Anthonsen et al., 1998; Holm, 2003). Especially Ser 563 and Ser 660 of adipose tissue HSL were phosphorylated after stimulation with epinephrine in cultured 3T3-L1 adipocytes (Anthonsen et al., 1998). The Ser 563 phosphorylation was associated with the onset of lactation and fat mobilization in s.c. adipose tissue of dairy cows (Elkins and Spurlock, 2009). The physiological role of Ser 660 phosphorylation in this species is currently unknown. Lipolytic capacity is not only dependent on metabolic and hormonal stimuli, but on the intrinsic lipolytic performance of different adipose tissue depots. In humans, visceral adipose tissue has a lower basal, but higher catecholamine-induced lipolysis in comparison to s.c. depots. This is based on a higher number of lipolytic $\beta$-adrenoceptors and a lower number of antilipolytic $\alpha$-adrenergic receptors (Yang and Smith, 2007). Studies on adipose tissue in cattle are mainly restricted to s.c. fat, and little is known about differences between visceral and s.c. depots. Wright and Russell (1984), cited in Rastani et al. (2001), found smaller proportions of fat in s.c. depots than in internal depots in Holstein cows in comparison to beef breeds despite comparable BCS. This suggests that visceral and s.c. depots might contribute to fat mobilization and increase in plasma NEFA concentrations differently.

The aim was to determine the expression of HSL and the extent of its phosphorylation at Ser 660 (HSLp660) and Ser 563 (HSLp563) in bovine adipose in response to the varying energy demands in periparturient dairy cows. In this context, the study focused on time-dependent changes and adipose depot-specific differences in HSL expression and phosphorylation. Moreover, by supplying a higher extent of postpartum dietary energy, it should be examined whether this additional exogenous energy would change the adaptive lipolytic response of adipose tissue in the periparturient dairy cow.

\section{MATERIALS AND METHODS}

\section{Animals and Feeding}

Twenty multiparous German Holstein cows were kept in a freestall housing system and stopped from lactating regularly about 8 wk before calving. At this time, all cows received the same diet. Throughout the dry period cows were fed a silage-based diet ( $40 \%$ grass silage and $60 \%$ corn silage on a DM basis). For transition feeding, starting $21 \mathrm{~d}$ prepartum, cows were offered concentrate at about $15 \%$ of DM of total ration. The day after calving, after the second biopsy sampling, cows were randomly assigned to 2 different feeding groups ( $\mathrm{n}=$ 10) until $21 \mathrm{~d}$ postpartum. All diets were fed individually as a TMR and differed in concentrate-to- roughage ratio on a DM basis. The high-concentrate $(\mathbf{H C})$ group received a diet with 60:40\% concentrate-to-roughage ratio and the low-concentrate $(\mathbf{L C})$ group received a diet with $30: 70 \%$ concentrate-to-roughage ratio. $\mathrm{Nu}$ trient, fiber, and energy contents of the different feed ingredients and diet composition are shown in Table 1. All feedstuff samples were analyzed according to the methods of the Verband Deutscher Landwirtschaftlicher Untersuchungs- und Forschungsanstalten (VDLUFA, 1997). The individual DMI was recorded by a computerized feeding system (Insentec BV, Marknesse, the Netherlands). Milk yield was recorded daily with a milk meter (Lemmer-Fullwood GmbH, Lohmar, Germany) and milk composition was analyzed twice weekly by a milk analyzer based on Fourier transform infrared spectroscopy (Milkoscan FT 6000; Foss Electric, Hillerød, Denmark). Daily data were pooled for each week of lactation. Energy balance (EB) was calculated as follows: $\mathrm{EB}=\mathrm{NE}_{\mathrm{L}}$ intake - energy in milk $-\mathrm{NE}_{\mathrm{M}}(\mathrm{GfE}$, 2001). During the experiment, no clinically relevant health problems occurred. Treatments were conducted according to the European Community regulations concerning the protection of experimental animals and the guidelines of the Lower Saxony State Office for Consumer Protection and Food Safety (LAVES), Germany (File number 33.14-42502-04-085/09).

\section{Blood Sampling and Analysis}

Blood samples were drawn weekly from the jugular vein, starting at d 21 prepartum until d 21 postpartum. Blood was centrifuged at $2,000 \times g$ for $10 \mathrm{~min}$ and serum and plasma were stored at $-80^{\circ} \mathrm{C}$. Serum was analyzed for NEFA and BHBA concentrations using an automatic analyzer system (Cobas Mira; F. Hoffmann- 
Table 1. Nutrient, fiber, and energy content of the feed ingredients as well as intended percentages of silage and concentrate in the diets fed to cows postpartum

\begin{tabular}{|c|c|c|c|c|}
\hline \multirow[b]{2}{*}{ Item $^{1}$} & \multicolumn{4}{|c|}{ Feeding component } \\
\hline & Corn silage & Grass silage & Concentrate $\mathrm{H}$ & Concentrate L \\
\hline $\mathrm{DM}(\mathrm{g} / \mathrm{kg})$ & 368 & 289 & 885 & 883 \\
\hline Ash $(\mathrm{g} / \mathrm{kg}$ of $\mathrm{DM})$ & 37 & 138 & 53 & 66 \\
\hline $\mathrm{CP}(\mathrm{g} / \mathrm{kg}$ of $\mathrm{DM})$ & 80 & 159 & 218 & 210 \\
\hline $\mathrm{EE}(\mathrm{g} / \mathrm{kg}$ of $\mathrm{DM})$ & 32 & 40 & 29 & 27 \\
\hline $\mathrm{ADF}(\mathrm{g} / \mathrm{kg}$ of $\mathrm{DM})$ & 223 & 311 & 52 & 53 \\
\hline $\mathrm{NDF}(\mathrm{g} / \mathrm{kg}$ of $\mathrm{DM})$ & 424 & 514 & 146 & 163 \\
\hline ME (MJ/kg of DM) & $10.7^{2}$ & $10.8^{2}$ & $13.1^{3}$ & $12.9^{3}$ \\
\hline $\mathrm{NE}_{\mathrm{L}}(\mathrm{MJ} / \mathrm{kg}$ of $\mathrm{DM})$ & $6.4^{2}$ & $6.5^{2}$ & $8.3^{3}$ & $8.2^{3}$ \\
\hline$\%$ in LC diet & 42 & 28 & 30 & - \\
\hline$\%$ in $\mathrm{HC}$ diet & 24 & 16 & - & 60 \\
\hline
\end{tabular}

La Roche Ltd., Basel, Switzerland). Glucose was determined in Na-fluoride plasma with the same system. Plasma insulin concentration (determined in EDTA plasma) was measured by RIA (IM3210, Immunotech; Beckman Coulter Inc., Brea, CA). The intra-assay coefficient of variation was $7.6 \%$ and the inter-assay $\mathrm{CV}$ was $10.7 \%$. The revised quantitative insulin sensitivity check index (RQUICKI) was calculated as proposed by Perseghin et al. (2001) and evaluated for cattle by Holtenius and Holtenius (2007). This index is based on plasma glucose (Gluc) in $\mathrm{mg} / \mathrm{dL}$, insulin (Ins) in $\mu \mathrm{U} / \mathrm{L}$, and NEFA in mmol/L concentrations and calculated as follows: RQUICKI $=1 /[\log ($ Gluc $)+\log ($ Ins $)+\log$ (NEFA)].

\section{Sampling of Adipose Tissue}

Adipose tissue samples were taken 3 times by biopsy, on d 21 prepartum, $1 \mathrm{~d}$ after calving and $21 \mathrm{~d}$ postpartum. After preparation of the surgical field and local infiltration anesthesia with procaine (Procaine 2\%; Selectavet Dr. Otto Fischer GmbH, Weyarn-Holzolling, Germany), samples from adipose tissue were taken under aseptic conditions from s.c. (SCAT) and retroperitoneal (RPAT) adipose tissue depots. A $1.5-\mathrm{cm}$ skin incision was made in the region of the tailhead on alternate sites to obtain SCAT. For collection of RPAT, a skin incision (about 3-cm long) was made in the angle between the lumbar transversal processus (about $5 \mathrm{~cm}$ ventrally) and the iliac bone (about $5 \mathrm{~cm}$ cranially), muscles were dissected reaching the peritoneum, and adipose tissue biopsies were taken directly above the peritoneum. Biopsies of RPAT were obtained each time alternating from the left and right flank. Skin incisions were closed with U-stitches (Filovet; Wirtschaftsgenossenschaft Deutscher Tierärzte, Garbsen, Germany).

\section{Processing of Adipose Tissue and Western Blot Analysis}

After a rinse in sterile saline solution to decrease surgically induced blood contamination, adipose tissue samples were immediately deep frozen in liquid nitrogen and stored at $-80^{\circ} \mathrm{C}$ until further analysis. For protein extraction, tissue was ground under liquid nitrogen and subsequently, about $50 \mathrm{mg}$ of tissue meal was homogenized in $1 \mathrm{~mL}$ of pre-chilled lysis buffer [in mmol/L: 50 HEPES, pH 7.4; 0.1\% Triton X-100 (Sigma-Aldrich, St. Louis, MO); 4 ethylene glycol-bis(2-amino-ethylether)$\mathrm{N}, \mathrm{N}, \mathrm{N}^{\prime}, \mathrm{N}^{\prime}$-tetra-acetic acid (EGTA); 10 EDTA; 100 $\beta$-glycerophosphate; 15 tetrasodium pyrophosphate; 5 sodium orthovanadate; 25 sodium fluoride; protease (complete mini; F. Hoffmann-La Roche Ltd.); and phosphatase inhibitors (PhosStop; F. Hoffmann-La Roche Ltd.)] and incubated for $1 \mathrm{~h}$ at $4^{\circ} \mathrm{C}$ under continuous shaking. Subsequently, the mixture was homogenized using a syringe and a 22 -gauge needle. The homogenate was gently centrifuged at $1,000 \times g$ for $10 \mathrm{~min}$ at $4^{\circ} \mathrm{C}$ to remove lipids and other particulate material. The liquid phase was collected and frozen in aliquots of 100 $\mu \mathrm{L}$ and stored at $-20^{\circ} \mathrm{C}$ until electrophoresis. Protein concentrations of the homogenates were measured according to Bradford (Bio-Rad protein quantification kit; Bio-Rad Laboratories Inc., Hercules, CA). Samples in loading buffer (50 mmol/L of Tris-HCL, pH 6.8, $10 \%$ glycerol, $2 \%$ SDS, $0.1 \%$ bromophenol blue, $2 \%$ mercaptoethanol) were denatured by heating them for 5 min at $95^{\circ} \mathrm{C}$ before loading $15 \mu \mathrm{g}$ per lane onto a $5 \%$ stacking and a $8.1 \%$ separation gel. Electrophoresis was carried out according to Laemmli (1970). Detection of specific proteins was performed after blocking the membranes in 10 and 5\%, respectively, fat-free milk/ PBS + 0.1\% Tween 20 (PBST; F. Hoffmann-La Roche 
Ltd.) at room temperature. Membranes were incubated overnight at $4{ }^{\circ} \mathrm{C}$ with primary antibodies against HSL, HSLp563, and HSLp660 (Cell Signaling Technology Inc., Danvers, MA) at a concentration of 1:1,000 and against $\beta$-actin (Sigma-Aldrich) at a concentration of 1:10,000. Antibodies against HSL and HSLp563 were already used for bovine adipose tissues by Elkins and Spurlock (2009). The antibody against HSLp660 is predicted to detect phosphorylation at Ser 659 of bovine HSL. Detection of the primary antibodies against HSL and its phosphorylated forms was performed using secondary anti-rabbit-HRP antibody (Cell Signaling Technology Inc.; 1:2,000) for $1 \mathrm{~h}$ at room temperature and against $\beta$-actin using secondary anti-mouse antibody (Sigma-Aldrich; 1:100,000). After washing twice in PBST and once in PBS for 5 min each, membranes were incubated with LumiGLO substrate (Kirkegaard and Perry Laboratories Inc., Gaithersburg, MD) and chemiluminescence was detected by a ChemiDoc system fitted with a digital camera (Bio-Rad Laboratories Inc.). Data were processed and analyzed by densitometry using Quantity One software (Bio-Rad Laboratories Inc.). To ensure that quantitative data were obtained, chemiluminescence signals were measured with at least 5 consecutive exposure times to determine the linear range of signal intensity of each antibody. Values of exposure times within the linear range were used for quantification. Specific band signals were normalized to the $\beta$-actin signal as an internal standard. To adjust signals from different membranes, 2 standard samples were blotted on each membrane. This allowed comparison of all membranes.

\section{Statistical Analysis}

Data were tested for Gaussian distribution using the Kolmogorov-Smirnov test. Differences between the LC and HC groups in DMI, milk yield, milk content, energy intake, and EB in the third and fourth week of lactation were assessed by unpaired Student's $t$-test for each week separately. The results of analyses performed after d 1 postpartum were analyzed by 2-way ANOVA for the factor time, including cow as a repeated factor, and concentrate feeding as an independent factor with the Bonferroni post-hoc test. If statistical differences related to the concentrate feeding postpartum were lacking, data of $\mathrm{HC}$ and LC feeding groups were pooled and analyzed by repeated measures 1-way ANOVA. In case of statistical differences between the $\mathrm{HC}$ and LC groups in blood metabolites at d 21 postpartum, these data were analyzed by unpaired Student's $t$-test. The HSL expression and the extent of its phosphorylation measured at d 21 postpartum were analyzed by 2-way ANOVA for the factor adipose tissue, including cow as a repeated factor, and concentrate feeding as an independent factor. If statistical differences related to the concentrate feeding postpartum were lacking, data of $\mathrm{HC}$ and $\mathrm{LC}$ feedings groups were pooled and analyzed for effects over time by repeated measures 1-way ANOVA for each tissue separately. The paired Student's t-test was used to assess differences between adipose tissue localizations.

\section{RESULTS}

\section{DMI, Energy Intake, Energy Balance, and Milk Yield and Composition}

For the third and fourth week of lactation, DMI, resulting $\mathrm{NE}_{\mathrm{L}}$ intake, milk yield and composition are in Table 2. The LC group ingested a diet composed of $31.9 \pm 2.1 \%$ concentrate and $68.1 \pm 2.1 \%$ roughage; whereas the corresponding proportions of the ration fed to the HC group were $59.7 \pm 6.5 \%$ and $40.3 \pm 6.5 \%$, respectively. Cows on the $\mathrm{LC}$ diet had a lower DMI $(P<0.01)$ during both weeks and consequently, lower energy intake. Milk yield was not affected by diet in the third week, but was lower $(P<0.05)$ in the fourth week of lactation in the LC group. In both groups, FCM was not influenced by concentrate feeding in the third and fourth week. The milk of the LC group was characterized by a higher $(P<0.05)$ percentage of milk fat in the third week of lactation. The milk protein content was not affected by diet. In wk 3 of lactation, the LC group experienced a more negative EB $(P<0.05)$ than the HC group (Table 2).

\section{Blood Metabolites and Insulin Sensitivity Index}

Blood analysis results and calculated RQUICKI values are in Table 3. No statistically detectable effect existed of $\mathrm{HC}$ or $\mathrm{LC}$ feeding after $\mathrm{d} 1$ postpartum on blood metabolites, except for BHBA. Therefore, the data of all cows were pooled and analyzed together, with the exception of BHBA values at d 21 (see below). On d 1 postpartum, serum NEFA concentrations were higher $(P<0.05)$ than prepartum concentrations and then started to decrease successively, resulting in lower $(P<0.05)$ concentrations $21 \mathrm{~d}$ postpartum than $1 \mathrm{~d}$ postpartum.

Concentrations of BHBA peaked on d 7 postpartum, but returned to the pre-calving level at $14 \mathrm{~d}$ postpartum. On d 21 postpartum, the BHBA concentration in the LC group was higher $(P<0.05)$ than in the $\mathrm{HC}$ group (LC: $0.77 \pm 0.05$ vs. HC: $0.47 \pm 0.11$ ). Plasma insulin concentrations were lower at $\mathrm{d} 1,7$, and 14 postpartum in comparison to d 21 prepartum $(P<0.05)$, whereas concentrations of glucose in plasma were lower 
Table 2. Dry matter intake and calculated $\mathrm{NE}_{\mathrm{L}}$ intake (NEI), energy balance (EB), milk yield, and milk contents in the third and fourth week of lactation in German Holstein cows fed diets with concentrate:roughage ratios of 30:70 $\left(\mathrm{LC} ;{ }^{2} \mathrm{n}=10\right)$ and $60: 40\left(\mathrm{HC} ;{ }^{3} \mathrm{n}=10\right)$, respectively, postpartum

\begin{tabular}{lccccc}
\hline & \multicolumn{2}{c}{ Third week of lactation } & & \multicolumn{2}{c}{ Fourth week of lactation } \\
\cline { 2 - 3 } \cline { 5 - 6 } Item & LC & HC & & LC & HC \\
\hline DMI (kg/d) & $16.3 \pm 0.42^{\mathrm{a}}$ & $18.9 \pm 0.74^{\mathrm{c}}$ & & $17.1 \pm 0.39^{\mathrm{a}}$ & $20.4 \pm 0.91^{\mathrm{c}}$ \\
NEI (MJ/d) & $113.7 \pm 2.85^{\mathrm{a}}$ & $141.7 \pm 5.51^{\mathrm{d}}$ & & $118.7 \pm 2.70^{\mathrm{a}}$ & $153.1 \pm 6.77^{\mathrm{d}}$ \\
Milk (kg/d) & $31.6 \pm 1.2$ & $37.2 \pm 2.5$ & & $32.1 \pm 1.0^{\mathrm{a}}$ & $40.1 \pm 2.3^{\mathrm{c}}$ \\
Milk fat (\%) & $5.01 \pm 0.17^{\mathrm{a}}$ & $4.30 \pm 0.20^{\mathrm{b}}$ & & $4.94 \pm 0.21$ & $4.40 \pm 0.30$ \\
Milk protein $(\%)$ & $3.13 \pm 0.07$ & $3.37 \pm 0.06$ & & $3.10 \pm 0.10$ & $3.22 \pm 0.08$ \\
FCM (kg/d) & $36.9 \pm 1.7$ & $38.4 \pm 3.4$ & & $42.8 \pm 3.5$ & $36.9 \pm 1.7$ \\
EB (MJ/d) & $-33.8 \pm 7.7^{\mathrm{a}}$ & $-15.3 \pm 6.0^{\mathrm{b}}$ & & $-27.9 \pm 5.6$ & $-14.9 \pm 9.2$ \\
\hline
\end{tabular}

\footnotetext{
${ }^{\mathrm{a}-\mathrm{d}}$ Superscripts indicate significant differences between the HC and LC group (columns) for each week separately, tested by unpaired Student's $t$-test $\left({ }^{\mathrm{a}, \mathrm{b}} P<0.05 ;{ }^{\mathrm{a}, \mathrm{c}} P<0.01 ;{ }^{\mathrm{a}, \mathrm{d}} P<0.001\right)$. Differences between weeks were not tested.

${ }^{1}$ Given are means \pm standard error of the means.

${ }^{2} \mathrm{LC}=$ low concentrate.

${ }^{3} \mathrm{HC}=$ high concentrate.
}

at d 7 postpartum in comparison to d 14 prepartum $(P<0.05)$. Calculation of RQUICKI showed lower $(P$ $<0.05)$ values on $\mathrm{d} 1$ postpartum in comparison to all sampling points prepartum.

\section{HSL Expression and Extent of Its Phosphorylation (HSLp660, HSLp563) in Adipose Tissue}

Time and Energy Intake-Dependent Changes. Representative specific bands of HSL, HSLp660, and HSLp563 protein in different adipose tissues and at the 3 sampling days are in Figure 1. Total HSL expression was lower at $1 \mathrm{~d}$ postpartum $(P<0.01)$ and $21 \mathrm{~d}$ postpartum $(P<0.05)$ in comparison to $21 \mathrm{~d}$ prepartum in SCAT, whereas in RPAT this difference only occurred between the first 2 sampling points (Figure $2 \mathrm{~A}$ and $\mathrm{B}$ ). Time-dependent phosphorylation of HSL at Ser 660 and Ser 563 during the periparturient period was observed. For HSLp660, phosphorylated protein increased only in RPAT $(P<0.05$; Figure $3 \mathrm{~A}$ and $\mathrm{B})$, whereas HSLp563 increased in both SCAT $(P<0.05)$ and $\operatorname{RPAT}(P<0.05$; Figure $4 \mathrm{~A}$ and $\mathrm{B})$. At $\mathrm{d} 21$ postpartum, a greater extent of Ser 563 phosphorylation was observed in RPAT of the HC fed group, resulting in an interaction $(P<0.05)$ between adipose tissue and concentrate feeding (Figure 5).

Localization-Dependent Changes. The HSL protein expression and extent of its phosphorylation at Ser 660 and Ser 563 were significantly higher in RPAT compared with SCAT 21 d postpartum (Table 4). Direct comparison between SCAT and RPAT $1 \mathrm{~d}$ postpartum and $21 \mathrm{~d}$ postpartum was not possible, for differences $(P<0.05)$ in $\beta$-actin protein expression occurred between the 2 depots.

\section{DISCUSSION}

\section{Metabolic Status of the Cows as Influenced by Time and by Postpartal Energy Intake}

The results of clinical blood analysis show the expected physiological changes in dairy cows during the

Table 3. Blood metabolites and revised quantitative insulin sensitivity index of German Holstein cows as influenced by the periparturient period $^{1}$

\begin{tabular}{|c|c|c|c|c|c|c|c|}
\hline Item & \multicolumn{7}{|c|}{ Days around calving $^{2}$} \\
\hline $\begin{array}{l}\text { Glucose }(\mathrm{mmol} / \mathrm{L}) \\
\text { NEFA }(\mu \mathrm{mol} / \mathrm{L}) \\
\text { Insulin }(\mu \mathrm{U} / \mathrm{L}) \\
\text { BHBA }(\mathrm{mmol} / \mathrm{L}) \\
\text { RQUICKI }^{3}\end{array}$ & $\begin{aligned} 3.89 & \pm 0.07^{\mathrm{ab}} \\
277 & \pm 40.2^{\mathrm{a}} \\
19.2 & \pm 2.48^{\mathrm{a}} \\
0.59 & \pm 0.04^{\mathrm{ab}} \\
0.41 & \pm 0.01^{\mathrm{a}}\end{aligned}$ & $\begin{aligned} 4.20 & \pm 0.27^{\mathrm{a}} \\
351 & \pm 96.6^{\mathrm{ac}} \\
16.3 & \pm 2.09^{\mathrm{ab}} \\
0.53 & \pm 0.03^{\mathrm{a}} \\
0.41 & \pm 0.01^{\mathrm{a}}\end{aligned}$ & $\begin{aligned} 3.75 & \pm 0.05^{\mathrm{ab}} \\
298 & \pm 36.3^{\mathrm{a}} \\
15.7 & \pm 1.46^{\mathrm{ab}} \\
0.57 & \pm 0.03^{\mathrm{ab}} \\
0.41 & \pm 0.01^{\mathrm{a}}\end{aligned}$ & $\begin{aligned} 3.86 & \pm 0.09^{\mathrm{ab}} \\
1,164 & \pm 112^{\mathrm{b}} \\
11.3 & \pm 1.87^{\mathrm{b}} \\
0.64 & \pm 0.04^{\mathrm{ab}} \\
0.36 & \pm 0.01^{\mathrm{b}}\end{aligned}$ & $\begin{array}{r}3.58 \pm 0.12^{\mathrm{b}} \\
1,219 \pm 116^{\mathrm{bc}} \\
9.33 \pm 1.80^{\mathrm{b}} \\
0.82 \pm 0.10^{\mathrm{b}} \\
0.38^{\mathrm{a}} \pm 0.02^{\mathrm{ab}}\end{array}$ & $\begin{aligned} 3.63 & \pm 0.09^{\mathrm{ab}} \\
1,002 & \pm 123^{\mathrm{bc}} \\
11.27 & \pm 1.58^{\mathrm{b}} \\
0.62 & \pm 0.09^{\mathrm{ab}} \\
0.38 & \pm 0.01^{\mathrm{ab}}\end{aligned}$ & $\begin{aligned} 3.68 & \pm 0.06^{\mathrm{ab}} \\
761 & \pm 119^{\mathrm{c}} \\
12.23 & \pm 1.39^{\mathrm{ab}} \\
& { }^{*} \\
0.38 & \pm 0.01^{\mathrm{ab}}\end{aligned}$ \\
\hline
\end{tabular}




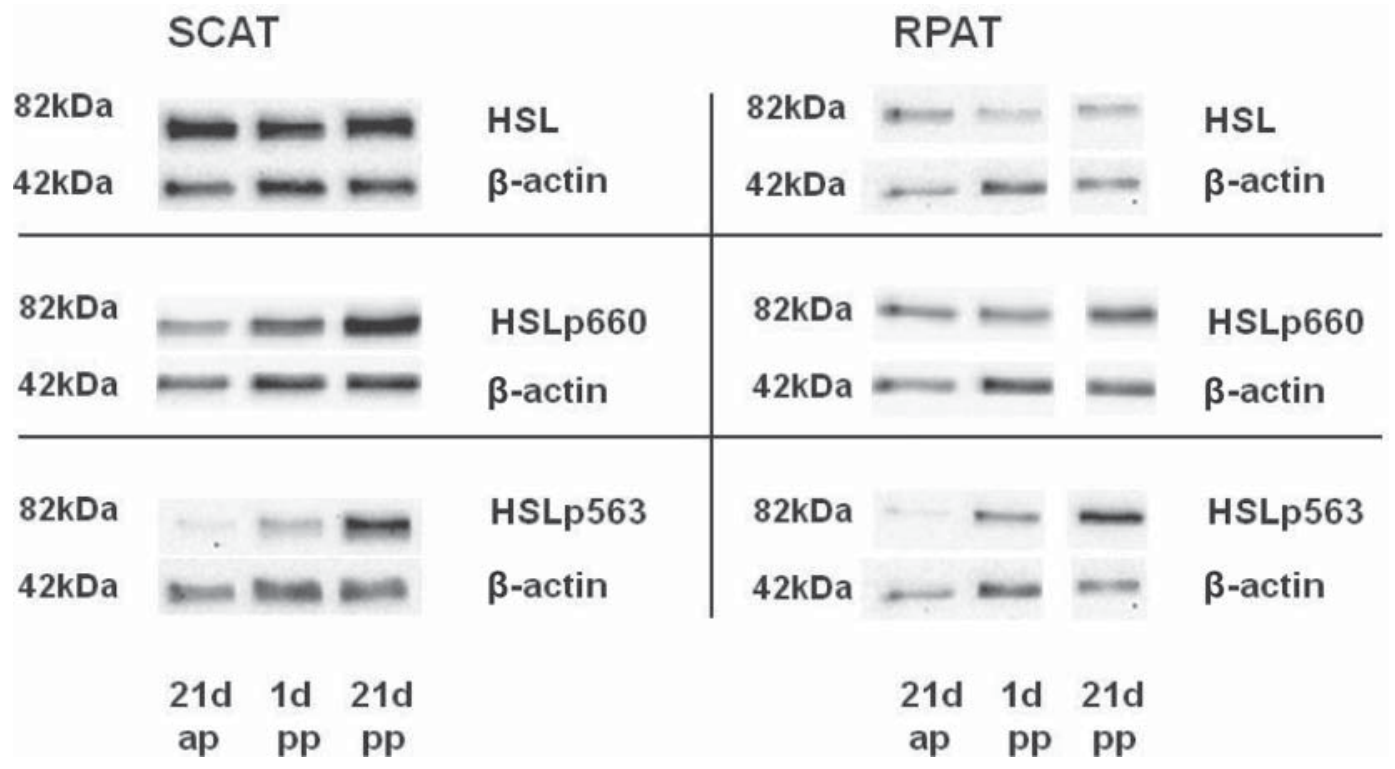

Figure 1. Hormone-sensitive lipase (HSL), HSL phosphorylated at Ser 660 (HSLp660) and at Ser 563 (HSLp563), and corresponding $\beta$-actin protein bands (representative Western blots) in s.c. (SCAT) and retroperitoneal (RPAT) adipose tissues of German Holstein cows at d 21 prepartum (ap) and d 1 and 21 postpartum (pp). The samples were run on different gels for each antibody and tissue.

periparturient period. The rise in NEFA concentrations reflected the adaptive lipolytic response to the increase in energy demand due to calving and the onset of lactation.

Reduced RQUICKI at d 1 postpartum could indicate lowered insulin sensitivity. As a measure indicating insulin sensitivity, RQUICKI has been assessed in cows in various physiological (Holtenius and Holtenius, 2007;
Bossaert et al., 2009) and pathophysiological (Kerestes et al., 2009; Stengärde et al., 2010) conditions in cattle. Its change has not been documented under physiological metabolic conditions in the transition from the dry period to early lactation in dairy cows yet. A decrease in insulin sensitivity may improve shifting of energy and nutrients from peripheral organs to the mammary gland.
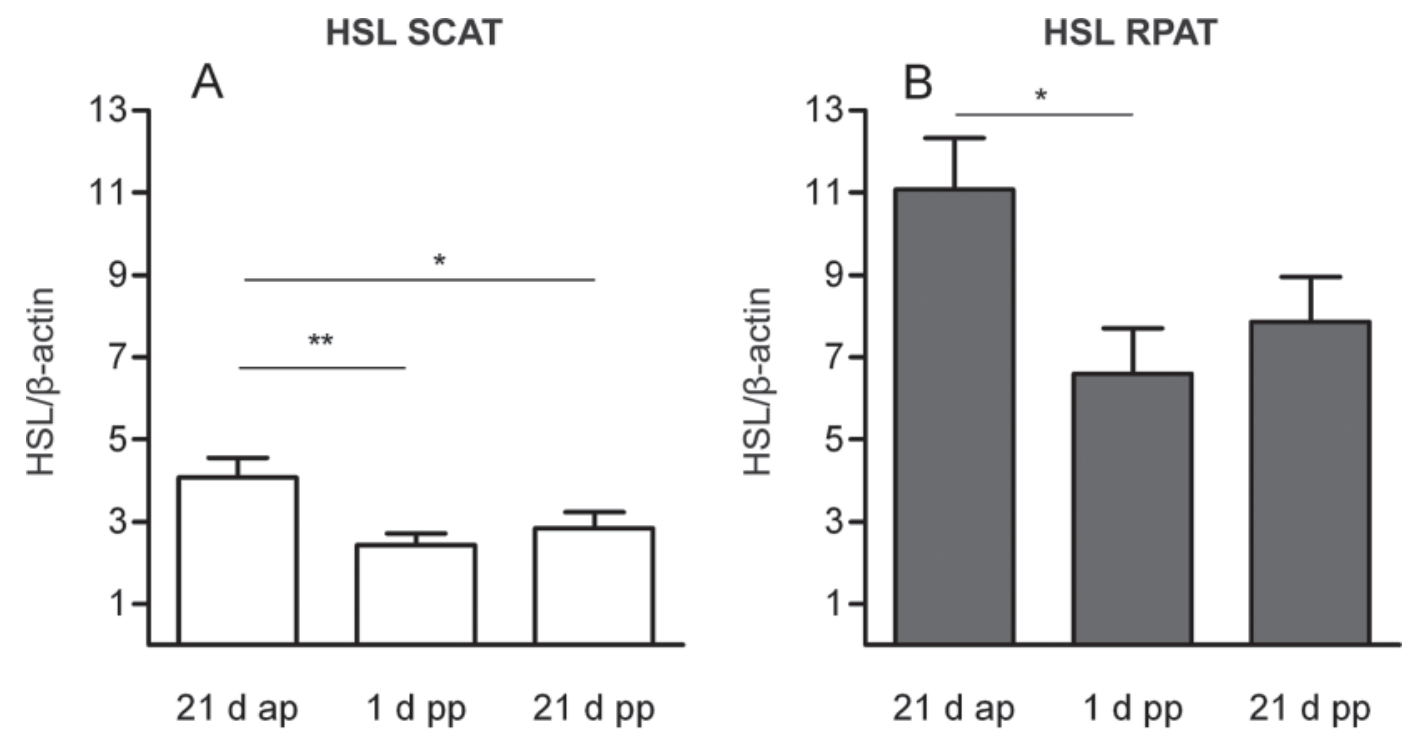

Figure 2. Hormone-sensitive lipase (HSL) protein expression in s.c. (SCAT; A) and retroperitoneal (RPAT; B) adipose tissues at d 21 prepartum (ap) and d 1 and 21 postpartum ( $\mathrm{pp}$ ) of German Holstein cows $(\mathrm{n}=20)$. Given are means \pm standard error of the means; asterisks indicate significant differences $\left({ }^{*} P<0.05 ;{ }^{* *} P<0.01\right)$ between sampling points tested with repeated measures 1 -way ANOVA and the post hoc Bonferroni procedure. 

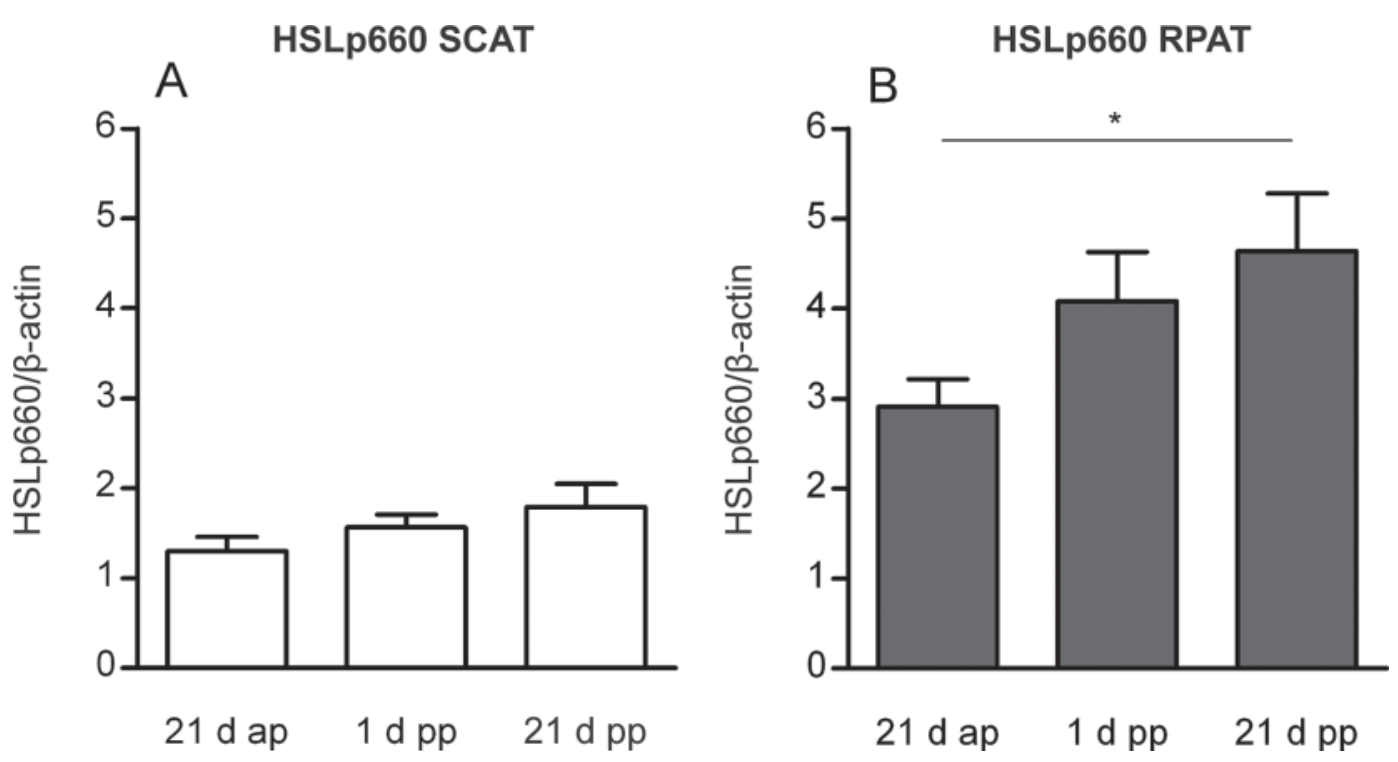

Figure 3. Extent of phosphorylation of hormone-sensitive lipase (HSL) at Ser 660 (HSLp660) in s.c. (SCAT; A) and retroperitoneal (RPAT; B) adipose tissues at d 21 prepartum (ap) and d 1 and 21 postpartum (pp) of German Holstein cows $(\mathrm{n}=20)$. Given are means \pm standard error of the means; asterisks indicate significant differences $\left({ }^{*} P<0.05\right)$ between sampling points tested with repeated measures 1-way ANOVA and the post hoc Bonferroni procedure.

\section{Time-Dependent Effects on Expression and Phosphorylation of HSL in Adipose Tissue}

A significant decrease in total HSL expression was observed after calving in both adipose tissue depots (Figure 2). Concomitantly with the decrease in HSL expression, plasma NEFA levels were high during the early postpartum period. The decrease in HSL expression could be based on a feedback mechanism responding to the increase of plasma NEFA postpartum. This might be based on a direct effect of NEFA on HSL expression. Regulatory molecular influences on HSL in ruminants have not been determined yet. Under consideration of lowered RQUICKI 1 d postpartum (Table
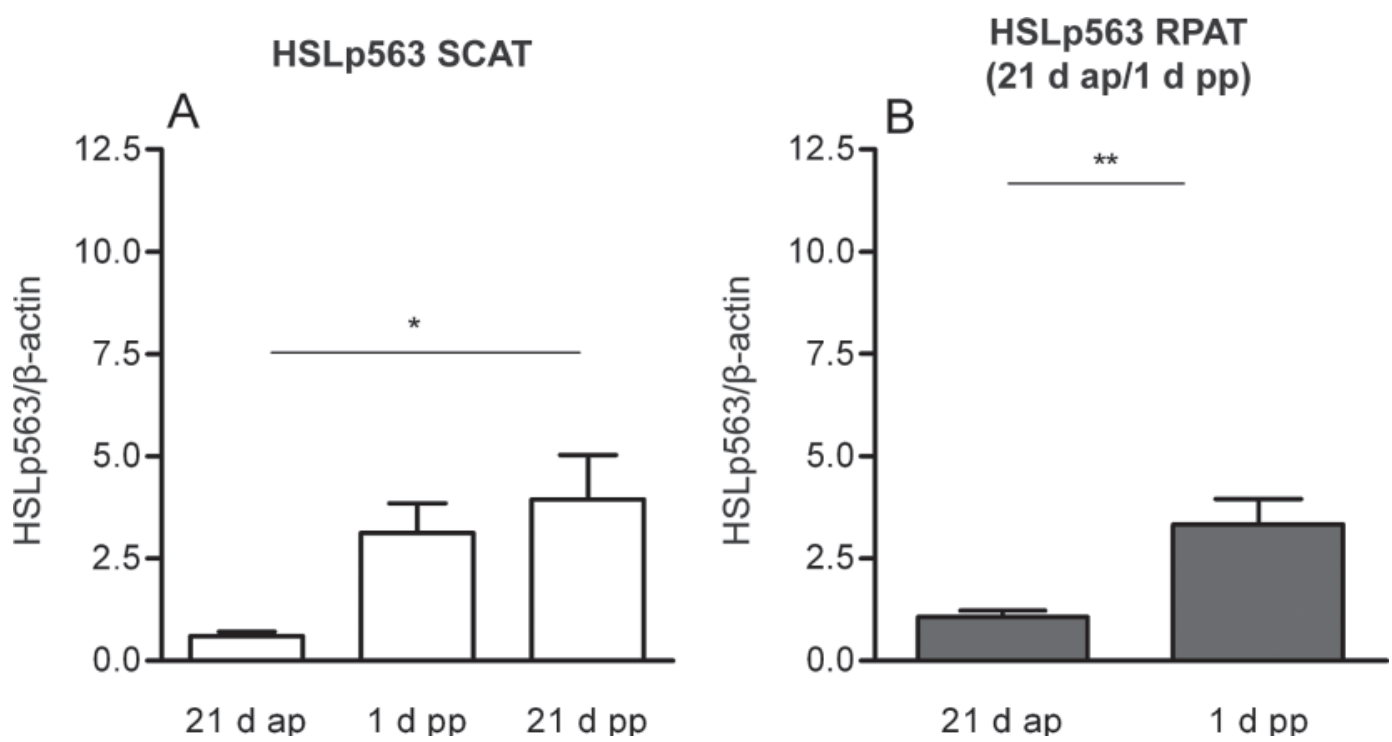

Figure 4. Extent of phosphorylation of hormone-sensitive lipase (HSL) at Ser 563 (HSLp563) in adipose tissue in German Holstein cows (n = 20) A: HSLp563 in s.c. adipose tissues (SCAT) at d 21 prepartum (ap) and d 1 and 21 postpartum (pp). Given are means \pm standard error of the means; asterisks indicate significant differences $(* P<0.05)$ between sampling points tested with repeated measures 1-way ANOVA and the post hoc Bonferroni procedure. B: HSLp563 in retroperitoneal adipose tissue (RPAT) at d 21 ap and d 1 pp. Given are means \pm standard error of the means; asterisks indicate significant differences $\left({ }^{* *} P<0.01\right)$ between sampling points tested with a paired Student's $t$-test. 
Table 4. Comparison of expression ${ }^{1}$ of hormone-sensitive lipase (HSL) and extent of phosphorylation at Ser 563 (HSLp563) and Ser 660 (HSLp660) between s.c. (SCAT) and retroperitoneal (RPAT) adipose tissue of Holstein dairy cows $21 \mathrm{~d}$ prepartum

\begin{tabular}{lrrr}
\hline Item & \multicolumn{1}{c}{ HSL } & HSLp660 & HSLp563 \\
\hline SCAT & $4.08^{\mathrm{a}} \pm 0.47$ & $1.30^{\mathrm{a}} \pm 0.16$ & $0.61^{\mathrm{a}} \pm 0.10$ \\
RPAT & $11.08^{\mathrm{d}} \pm 1.25$ & $2.91^{\mathrm{d}} \pm 0.30$ & $1.03^{\mathrm{b}} \pm 0.15$ \\
\hline
\end{tabular}

$\overline{{ }^{\mathrm{a}-\mathrm{d}} \text { Superscripts indicate significant differences }\left({ }^{\mathrm{a}, \mathrm{b}} P<0.05 ;{ }^{\mathrm{a}, \mathrm{d}} P<0.001\right) \text { between adipose tissue localizations }}$ (rows), tested with paired Student's t-test.

${ }^{1}$ Given are means \pm standard error of the means of semiquantitative Western blot analyses.

3), this might be associated with impaired insulin action, for a decrease in HSL expression is described in insulin-resistant humans (Lafontan and Langin, 2009). It has been known that during lactation the number of $\beta$-adrenergic receptors in bovine s.c. adipose tissue increases, facilitating the mobilization of fat reserves (Jaster and Wegner, 1981). This increase in $\beta$-adrenergic receptors and thereby, an enhancement of catecholamine response in adipose tissue, might be the reason for the rise in HSL phosphorylation. In this study, 2 HSL phosphorylation sites were examined for the first

HSLp563 21 d pp LC/HC

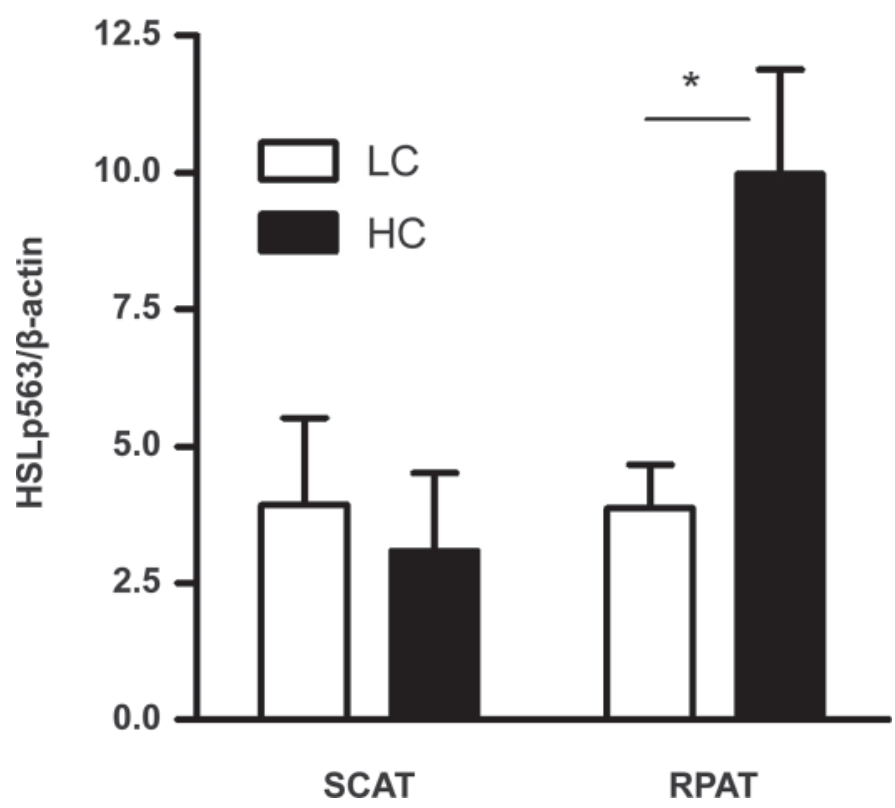

Figure 5. Extent of phosphorylation of hormone-sensitive lipase (HSL) at Ser 563 (HSLp563) in s.c. (SCAT) and retroperitoneal adipose tissue (RPAT) in German Holstein cows. Given are means \pm standard error of the means; asterisks indicate significant differences $\left({ }^{*} P<0.05\right)$ between the high-concentrate group (HC; concentrate-toroughage ratio 60:40\%) and the low-concentrate group (LC; concentrate-to-roughage ratio 30:70\%) tested with repeated measures 2-way ANOVA, including factors concentrate and tissue, and the post hoc Bonferroni procedure. time in cattle. The HSLp660 antibody revealed a specific signal for phosphorylation in bovine adipose tissues indicating the existence of another phosphorylation site at the HSL molecule. At position 659 of bovine HSL AA sequence [National Center for Biotechnology Information (NCBI) accession number NP_001073689.1], a serine is expressed, which is known from other species to be phosphorylated by PKA (Holm, 2003). But, in the following text, according to the detecting antibody, the serine phosphorylation at this site is named as HSLp660 and Ser 660, respectively. The HSLp563 antibody has been used in bovine adipose tissues by Elkins and Spurlock (2009) and might be able to detect the serine at position 564 in the bovine HSL AA sequence. In the following text, serine phosphorylation at this site is named HSLp563 and Ser 563, respectively, according to the detecting antibody. The extent of phosphorylation of HSL at Ser 660 in RPAT (Figure 3) and at Ser 563 (Figure 4) in both adipose tissues increased during the periparturient period to cover enhanced energy demand by lipolysis and release of NEFA into the plasma. The Ser 660 site is considered a crucial phosphorylation site for HSL activity in adipose tissue in humans by translocating HSL to the lipid droplet surface, whereas the role of Ser 563 remains elusive (Holm, 2003). An important physiological role of HSLp563 in modulating lipolysis in the periparturient cow was discussed by Elkins and Spurlock (2009), who showed an upregulation of HSLp563 in early lactation in s.c. adipose tissue of dairy cows. In the present study, HSLp660 could be detected before calving in a period when energy balance was positive in all cows. Distinct signals for HSLp563 were often very low or below detectable levels (see Figure 1). Later on, during transition, the extent of HSL phosphorylation at Ser 563 was increased in all cows. This indicates that Ser 563 is phosphorylated in times of increasing fat mobilization. Whether this phosphorylation site is closely associated with or responsible for a higher lipolytic capacity in bovine adipose tissue still needs to be proved. Hence, a complex interplay of phosphorylation sites of HSL is assumed to be involved in the regulation of lipolysis in cows as described for adipocytes in vitro (Martin et al., 2009). 


\section{Localization-Dependent Effects on Expression and Phosphorylation of HSL}

According to Wajchenberg (2000) RPAT is an abdominal visceral depot. Visceral adipocytes of rodents and humans are supposed to have a more sensitive lipolytic system to endocrine stimuli compared with s.c. adipocytes (Montague and O'Rahilly, 2000). This was associated with higher expression of $\beta$-adrenergic receptors (Arner et al., 1990). In the present study, higher expression of HSL and extent of phosphorylation at Ser 660 and Ser 563 in RPAT 21 d prepartum (Figure 3; Table 4) might reflect a higher potential to respond to catecholamine-driven stimulation in visceral adipose tissue of dairy cows.

\section{Energy Intake-Dependent Effects on Expression and Phosphorylation of HSL}

The total HSL expression and extent of phosphorylation at Ser 660 was not influenced by energy intake at d 21 postpartum in both adipose tissues. Cows in the HC group with higher energy intake (Table 2) showed a significantly higher extent of phosphorylation at Ser 563 in RPAT compared with the low-energy intake LC cows at d 21 postpartum (Figure 5). Again this indicates the metabolic importance of RPAT in dairy cows regarding its capacity for lipolytic adaptation. Furthermore, postpartum dietary intervention was associated to depot-specific regulation of lipolysis. Despite the higher extent of HSL phosphorylation, serum NEFA concentrations did not reflect differences in lipolysis postpartum (Table 2). Furthermore, efficient utilization of NEFA for energy production for the mammary gland in the $\mathrm{HC}$ group might have resulted in the lack of differences in plasma NEFA concentrations between both groups. The surplus of energy in the HC group in comparison to the LC group could have been used for lactose synthesis by the mammary gland, leading to an increased milk yield, which was observed in the third week and more pronounced in the fourth week postpartum in $\mathrm{HC}$ cows. This was also reflected in decreased fat content in the third week postpartum. Concomitantly, EB was less negative in these HC-fed dairy cows (Table 2). Higher plasma BHBA concentrations of the LC group might be responsible for inhibition of phosphorylation at Ser 563 of HSL. Even in the range of physiological serum concentrations, BHBA can inhibit catecholamine-induced lipolysis in bovine adipocytes, indicating a negative feedback mechanism of lipid metabolism in case of inefficient fatty acid oxidation (Metz et al., 1974). The ketone body BHBA is a natural ligand for the GPR109A receptor, which is coupled to an inhibitory $G$ protein that decreases
cAMP production and, thereby, PKA-driven HSL phosphorylation in nonruminant species (Taggart et al., 2005). Furthermore, Martin et al. (2009) showed in in vitro studies with cultured adipocytes that PKA activation by adrenergic stimulation and subsequent cAMP increase leads to spatial and temporal different reactions in the adipocyte. Phosphorylation of HSL at Ser 660 was important for translocation of HSL to the lipid droplet and initiation of lipolysis and occurred immediately after $\beta$-adrenergic stimulation, whereas Ser 563 phosphorylation occurred temporally later and might play a role in stabilization of the lipolytic action. The exact functional role of Ser 563 phosphorylation remains unclear. Extrapolating these findings to the results of the present study, higher HSLp563 phosphorylation in the $\mathrm{HC}$ group might reflect a more efficient lipolytic situation. Time-dependent phosphorylation of Ser 660 was unaffected, whereas a decrease in phosphorylation of Ser 563 occurred, resulting in probably less lipolytic activity.

\section{CONCLUSIONS}

Phosphorylation of HSL at Ser 660 and Ser 563 seemed to play a role in the lipolytic response of bovine adipose tissues in the periparturient period. But, the exact physiological role of Ser 660 and Ser 563 phosphorylation sites of HSL still remains unclear in dairy cows. High energy intake postpartum elicits adipose depot-specific stronger lipolytic responses consistently, with an amelioration of catabolic state by improving fatty acid utilization in dairy cows. On d 21 prepartum in RPAT, higher HSL protein expression and extent of phosphorylation could be shown, possibly indicating a higher lipolytic potential for this depot. Therefore, this depot may play a special role in pathophysiology of dairy cow lipomobilization.

\section{REFERENCES}

Anthonsen, M. W., L. Rönnstrand, C. Wernstedt, E. Degerman, and C. Holm. 1998. Identification of novel phosphorylation sites in hormone-sensitive lipase that are phosphorylated in response to isoproterenol and govern activation properties in vitro. J. Biol. Chem. 273:215-221.

Arner, P., L. Hellström, H. Wahrenberg, and M. Brönnegård. 1990. Beta-adrenoceptor expression in human fat cells from different regions. J. Clin. Invest. 86:1595-1600.

Bossaert, P., J. L. M. R. Leroy, S. De Campeneere, S. De Vliegher, and G. Opsomer. 2009. Differences in the glucose-induced insulin response and the peripheral insulin responsiveness between neonatal calves of the Belgian Blue, Holstein Friesian, and East Flemish breeds. J. Dairy Sci. 92:4404-4411.

Drackley, J. K. 1999. Biology of dairy cows during the transition period: The final frontier? J. Dairy Sci. 82:2259-2273.

Elkins, D. A., and D. M. Spurlock. 2009. Phosphorylation of perilipin is associated with indicators of lipolysis in Holstein cows. Horm. Metab. Res. 41:736-740. 
GfE (Society of Nutrition Physiology). 2001. Empfehlungen zur Energie- und Nährstoffversorgung der Milchkühe und Aufzuchtrinder. Energie- und Nährstoffbedarf landwirtschaftlicher Nutztiere. Nr. 8. DLG-Verlag, Frankfurt am Main, Germany.

Hayirli, A. 2006. The role of exogenous insulin in the complex of hepatic lipidosis and ketosis associated with insulin resistance phenomenon in postpartum dairy cattle. Vet. Res. Commun. 30:749-774.

Holm, C. 2003. Molecular mechanisms regulating hormone-sensitive lipase and lipolysis. Biochem. Soc. Trans. 31:1120-1124.

Holtenius, P., and K. Holtenius. 2007. A model to estimate insulin sensitivity in dairy cows. Acta Vet. Scand. 49:29.

Ingvartsen, K. L., and J. B. Andersen. 2000. Integration of metabolism and intake regulation: A review focusing on periparturient animals. J. Dairy Sci. 83:1573-1597.

Jaster, E. H., and T. N. Wegner. 1981. Beta-adrenergic receptor involvement in lipolysis of dairy cattle subcutaneous adipose tissue during dry and lactating state. J. Dairy Sci. 64:1655-1663.

Kerestes, M., V. Faigl, M. Kulcsár, O. Balogh, J. Földi, H. Fébel, Y. Chilliard, and G. Huszenicza. 2009. Periparturient insulin secretion and whole-body insulin responsiveness in dairy cows showing various forms of ketone pattern with or without puerperal mastitis. Domest. Anim. Endocrinol. 37:250-261.

Laemmli, U. K. 1970. Cleavage of structural proteins during the assembly of the head of bacteriophage T4. Nature 227:680-685.

Lafontan, M., and D. Langin. 2009. Lipolysis and lipid mobilization in human adipose tissue. Prog. Lipid Res. 48:275-297.

Martin, S., S. Okano, C. Kistler, M. A. Fernandez-Rojo, M. M. Hill, and R. G. Parton. 2009. Spatiotemporal regulation of early lipolytic signaling in adipocytes. J. Biol. Chem. 284:32097-32107.

Metz, S. H., M. Lopes-Cardozo, and S. G. van den Bergh. 1974. Inhibition of lipolysis in bovine adipose tissue by butyrate and betahydroxybutyrate. FEBS Lett. 47:19-22.

Montague, C. T., and S. O'Rahilly. 2000. The perils of portliness: Causes and consequences of visceral adiposity. Diabetes 49:883888.

Nilsson, S., C. Holm, and P. Belfrage. 1989. Rapid purification of detergent-solubilized bovine hormone-sensitive lipase by high performance hydrophobic interaction chromatography. Biomed. Chromatogr. 3:82-87.

Perseghin, G., A. Caumo, M. Caloni, G. Testolin, and L. Luzi. 2001. Incorporation of the fasting plasma FFA concentration into QUICKI improves its association with insulin sensitivity in nonobese individuals. J. Clin. Endocrinol. Metab. 86:4776-4781.

Rastani, R. R., S. M. Andrew, S. A. Zinn, and C. J. Sniffen. 2001. Body composition and estimated tissue energy balance in Jersey and Holstein cows during early lactation. J. Dairy Sci. 84:12011209.

Stengärde, L., K. Holtenius, M. Tråvén, J. Hultgren, R. Niskanen, and U. Emanuelson. 2010. Blood profiles in dairy cows with displaced abomasum. J. Dairy Sci. 93:4691-4699.

Sumner, J. M., and J. P. McNamara. 2007. Expression of lipolytic genes in the adipose tissue of pregnant and lactating Holstein dairy cattle. J. Dairy Sci. 90:5237-5246.

Taggart, A. K., J. Kero, X. Gan, T. Q. Cai, K. Cheng, M. Ippolito, N. Ren, R. Kaplan, K. Wu, T. J. Wu, L. Jin, C. Liaw, R. Chen, J. Richman, D. Connolly, S. Offermanns, S. D. Wright, and M. G. Waters. 2005. (D)- $\beta$-Hydroxybutyrate inhibits adipocyte lipolysis via the nicotinic acid receptor PUMA-G. J. Biol. Chem. 280:26649-26652.

VDLUFA (Verband Deutscher Landwirtschaftlicher Untersuchungsund Forschungsanstalten) 1997. VDLUFA-Methodenbuch. Band III: Die chemische Untersuchung von Futtermitteln. Ergänzungslieferungen von 1983, 1988, 1992, 1997, 2004, 2006, 2007. VDLUFA, Darmstadt, Germany.

Wajchenberg, B. L. 2000. Subcutaneous and visceral adipose tissue: Their relation to the metabolic syndrome. Endocr. Rev. 21:697738.

Wright, I. A., and A. J. F. Russell. 1984. Partition of fat, body composition and body condition score in mature cows. Anim. Prod. $38: 23-32$.

Yang, X., and U. Smith. 2007. Adipose tissue distribution and risk of metabolic disease: Does thiazolidinedione-induced adipose tissue redistribution provide a clue to the answer? Diabetologia 50:1127-1139. 